This is a draft article. The final version is available in Entrepreneurship, innovation and education: frontiers in European entrepreneurship research edited by U. Hytti, R. Blackburn \& E. Lavren published in 2018, Edward Elgar Publishing Ltd.

Joensuu-Salo, S., Sorama, K. \& Kettunen, S. 2018. Internationalized SMEs: the impact of market orientation and marketing capability on business performance. In: U. Hytti, R. Blackburn \& E. Lavren (eds.) Entrepreneurship, innovation and education : frontiers in European entrepreneurship research. Cheltenham : Edward Elgar, 84-102. ISBN: 978-1$78897-229-1$

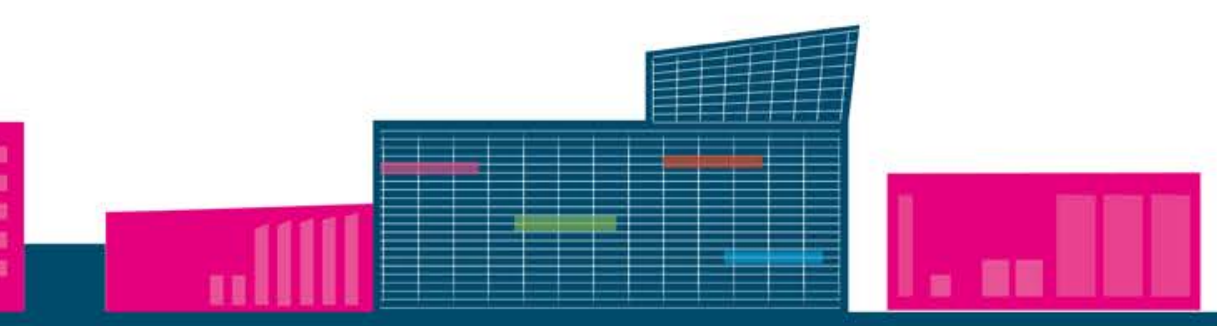




\title{
Internationalized SMEs: The Impact of market orientation and marketing capability
}

\section{on business performance}

\author{
Sanna Joensuu-Salo, Kirsti Sorama \& Salla Kettunen \\ Seinäjoki University of Applied Sciences, Finland \\ sanna.joensuu-salo@seamk.fi
}

\section{Introduction}

The growth and success of SMEs has been one of the most important issues in Finland in recent years. Especially in the Forest sector, internationalization has been seen as a prerequisite for growth. The degree of internationalization varies across the sectors: e.g. in a study of Kettunen (2013), the share of export was over 50 percent in sawmill industry and in other sectors the share of export was usually under 10 percent.

Existing research has shown that market orientation and marketing capability have either direct or indirect effect on business performance and success (Narver \& Slater, 1990; Vorhies, Orr \& Bush, 2011). It could be assumed that when operating on foreign markets, these concepts are even more important. Firm's global market orientation by itself is an idiosyncratic competence thereby supporting the firm's activities in its markets. Market orientation can be embodied as an antecedent of the internationalization process of a SME (Wright, Westhead \& Ucbasaran, 2007).

However, there is still a gap in literature exploring the interplay of market orientation and marketing capability in internationalization process. Also, the effect of market orientation and marketing capability on firm performance within international markets is not well examined especially with SMEs. In Finland, the Forest sector is an important part of the whole economy and has been in a major turbulence. It is important to develop competences of small and medium-sized firms to 
succeed in international markets. This research contributes to the literature in two important ways. First, it analyzes the role of market orientation and marketing capability in SMEs operating in the Forest sector. Second, this study brings new knowledge about the interplay of market orientation and marketing capability in the internationalization process of SMEs.

The objectives of the present study are to analyze (1) the impact of market orientation and marketing capability on business performance with SMEs in the Forest sector and (2) the difference of this impact between internationalized SMEs and SMEs operating only on domestic markets in the Forest sector.

\section{Theoretical framework}

\subsection{Factors influencing the internationalization of SMEs in the Forest Sector}

Forest sector in its different forms has traditionally been important for Finland. In South and Central Ostrobothnia mechanical wood industry (sawmill, building, engineered wood products, furniture) forms a notable cluster also in the national scale. Many of these industries face growing and hard competition from international markets, which, combined to chancing customer behaviour, has already led to big structural changes. Working in domestic markets requires therefore also understanding from international markets. Internationalization provides bigger market areas and decreases the risk during recession in domestic market. New technology and materials should be utilized in order to stay in the cutting edge of the industry (Loukasmäki, 2015).

The growth and internationalization of the forest sector, and especially wood products, has been studied in the Strategic program of the forest sector. It reviles, that the obstacles to growth and internationalization for the small firms are mainly internal, whereas the operational environment mainly sets the boundaries to bigger firms. Within the wood product industry, the internal barriers 
are formed by lack of co-operation and networking; shortages in sales and marketing know-how; building a brand; the dearth of internationalization planning and dearth of exports promotion; lack of strategic and internationalization knowledge; business development and capability of revision in the firms; family business may withdraw too much; what the spirit and will to growth in the firm is. Operational environment includes things like the collative agreements and high level of labor costs; how to finance internationalization; how to recognize financing and advisory services (small firms); the disappearance of basic industry from Finland; cheap imported goods; subsidy politics of the EU deforms competition in the European internal markets. Interviews resulted in own strong working and making in the firm, technically high quality products, strong product planning/ design, personnel, competence and family firms as internal strengths. (Kettunen, 2013.)

Continuous lack of resources and lack of knowledge formed barriers to the internationalization of the wood product industry. Internationalization in the firms should be seen as a strategic goal and clear action plan should be made how the goal can be reached. When the needed competence of the personnel is estimated, also experience from international business could be included. Customer orientation in the products and keeping up a good service level are essential factors also in the export countries. A product that is successful in domestic markets may need some changes when it is taken to other market area. Also the service needs to work in external markets. It is important to succeed in charting the right marketing channels and find an effective way for distribution and sales. (Kettunen, 2013.)

Competing by quality in the Forest sector requires standardization, CE marking, planning tools and data models. If there is only one supplier to wood products or parts, there is a risk for the buyer especially in construction. Therefore competition and many suppliers is also a positive thing. Also the processing, distribution channels and product know-how needs to be in order. (Heino, 2011; 
Hurmekoski, Jonsson \& Nord, 2015.) In the field of wood product industry there are several associations, which aim at influencing the regulations, rules and their interpretation, standardizing products and networking.

\subsection{Market orientation}

Market orientation (MO) is the basis of marketing and strategic planning (Narver \& Slater, 1990) and entails the processes of a firm implementing marketing concepts in practice (Kohli, Jaworski \& Kumar, 1993). Marketing concept means how a firm can find needs and wants in the market and use these needs as a basis of product/service development better than competitor (Slater \& Narver, 1998). Three different elements have been identified in MO: customer orientation, competitor orientation and interfunctional coordination (Narver \& Slater, 1990). Customer and competitor orientation refer to active information generation from customers and competitors through monitoring market needs and wants. Interfunctional coordination refers to the firm's ability to disseminate this information throughout the firm in a way that creates value to the customer through products and services. Jaworski and Kohli (1993) identify three phases in the process: 1) generating market information from customer's present and future needs, 2) sharing market knowledge within the firm and 3) answering to customer's present and future needs. In Homburg and Pflesser's (2000) view, MO consists of different perspectives such as values, norms, artifacts and behavior. MO can thus be seen as an embedded cultural state which has an effect on the different activities in firms. However, MO can also be viewed as a strategic option, deliberately chosen in order to enhance performance.

In terms of $\mathrm{MO}$, firms can be classified in different ways. Some scholars view $\mathrm{MO}$ as a continuum along which firms can be placed, i.e. firms can adopt different levels of MO. Others view MO as dichotomous: a firm either is or is not market oriented (Harris, 1999). MO has also been viewed as a resource in a learning organization (Hunt \& Morgan, 1995), in which case MO is considered a resource 
for generating information to help the firm to develop products and services with better value for the customer. Hurley and Hult (1998) argue that, for growth and productivity, it is not MO itself that is relevant but rather the development of the firm's competencies through MO.

Market orientation has attracted wide research efforts over the past years, with the studies highly concentrated on MO's effect on business performance. Prior research indicates that $\mathrm{MO}$ is related to business performance either directly or indirectly (e.g. Verhoef et al., 2011; Narver \& Slater, 1990; Pelham, 2000; Maydeu-Olivares \& Lado, 2003; Matsuno, Mentzer \& Özsomer, 2002; Shin \& Aiken, 2012). Also studies using meta-analyses confirm the positive effect of MO to business performance (Cano, Carrillat \& Jaramillo, 2004; Kirca, Jayachandran \& Bearden, 2005). The same result has been found also in microenterprises by Spillan et al. (2013). Jain et al. (2013) propose integrated framework of antecedents and effects of market orientation based on earlier research. They also argue that there is a positive, significant and robust link between market orientation and firm performance.

Contradictory results exist concerning the effect of MO on profitability. Narver \& Slater (1990) find that MO has a substantial positive and direct effect on profitability in both commodity products businesses and noncommodity businesses. Morgan (2015) examines also the dark side of market orientation. He states that if a firm implements both market orientation and entrepreneurial orientation philosophy, it may hinder new product development performance. However, a high market orientation may help reduce consumer learning and enhance the adoption of radical new products.

Pelham (1997) suggests that MO has an indirect effect on profitability through firm effectiveness and growth/share (Pelham, 1997). Also Slater and Narver (1994) confirm MO's effect on sales growth. In addition, Pelham (2000), in a study of MO in small firms, finds that it has a critical role in implementing 
a growth strategy. In conclusion, MO has either direct or indirect effect on profitability and has a role in growth.

\subsection{Marketing capability}

According to resource-based view (RBV), a firm can be viewed as a bundle of resource, and competitive advantage is based on possession of valuable and rare resources. Little utilized in the field of marketing (Srivastava, Fahey \& Christensen, 2001), the RBV has been later complemented by a view emphasizing dynamic capabilities (DC), which highlights the ability of a firm to adjust its processes so as to utilize resources effectively in a dynamic business environment; in the DC view competitive advantage stems not just from resources but rather from new resource configurations based on dynamic capabilities (Cavusgil, Seggie \& Talay, 2007). According to Day (1994), capabilities are complex bundles of skills and knowledge accumulated in the firm and applied in organizational processes.

Day (1994) categorized marketing capabilities as outside-in -capabilities (e.g. market information, customer relations), inside-out -capabilities (logistics, cost control) and integration capabilities (pricing, product/service development). He considers in particular the capabilities connected to understanding the markets and customer focused marketing capabilities central for market oriented firms. Hooley et al. (1999) see capabilities in three different levels; they argue that the capabilities presented by Day (1994) are in the operational level but more important capabilities are in the firm's cultural and strategic level.

Reijonen and Komppula (2010) found that although market orientation and in particular customer orientation have been adopted to some degree among Finnish SMEs, there are considerable gaps in marketing capabilities. Since marketing process tend to develop on firm level, capabilities also evolve 
individually, potentially producing unique ways of utilizing competencies. Srivastava, Fahey and Christensen (2001) emphasize the creation of customer value based on knowledge and relationship resources within innovation, value chain and customer relationship management processes. As markets become increasingly complex, dynamic capabilities are also increasingly important: the ability to learn from market information, to experiment flexibly, to market in a way that builds relationships (Day 2011).

The emphasis on dynamic capabilities highlights the importance of strategic level adoption of MO. Vorhies and Harker (2000) found in their study that firms with high MO also had higher levels of the six marketing capabilities, these being marketing research, product development, pricing, distribution, promotion and marketing management. In further study on customer focused marketing capabilities, an impact on financial performance from capabilities in brand management and customer relationship management was found (Vorhies, Orr \& Bush, 2011). The latter enables efficient deployment of relationship resources and the former of reputational resources. Also Wilden and Gudergan (2015) found that marketing capabilities are positively associated with firm performance in highly competitive environments.

Foley and Fahy (2009) argue that market orientation and marketing capability are linked. Recent research has shown that marketing capability mediates the effect of market orientation (Shin \& Aiken, 2012; Merrilees, Rundle-Thiele \& Lye, 2011). This was also found in Finnish SME's; especially with growth firms, market orientation had an indirect effect on business performance mediated by marketing capability (Joensuu et al., 2015). Jain et al. (2013) also state that in earlier research, it has been found a close association between market orientation and marketing planning/operational marketing strategies. By developing firm's market orientation, the firm's marketing capabilities also 
may develop and in the long run, resulting in sustainable competitive advantage. In sum, it appears $\mathrm{MO}$ and marketing capabilities are linked, and have a connection with business performance.

\subsection{Internationalization}

In the theory of the internationalization of firm there is no single explanatory factor, so the researchers propose that internationalization must be considered a combination of several different perspectives (Chetty \& Campbell-Hunt, 2003). With the advent of globalization and the knowledge economy, an important issue lies in the strategic capabilities that enable the internationalization of SMEs. The ability to internationalize has become a competitive necessity for many firms, enabling survival and growth under globalization (Acs et al., 2003; Knight, 2000; Couerderoy et al., 2011). Correspondingly, this phenomenon has received increasing attention from scholars who have sought to characterize the internationalization process and export behavior of SMEs (Moen \& Servais, 2002), be it incremental as in the Uppsala model and the network approach (e.g. Johanson \& Vahlne, 2009) or radical as in the 'born-global' firms (e.g. Freeman \& Cavusgil, 2007), and to identify the antecedents and consequences of internationalization (Coviello \& McAuley, 1999; Higon \& Driffield, 2011; Ruzzier et al., 2006; Sousa et al., 2008).

Small and medium size enterprises (SMEs) play an important role in international markets. SMEs are usually limited in their resources and international experience. Strategy and entrepreneurship scholars argue that firms succeed by building and retaining a competitive advantage. For example, Ireland, Hitt and Simon (2003) integrated theories from strategy and entrepreneurship disciplines to explain how firms develop and sustain these advantages. They noted that firms succeed by identifying and exploiting new opportunities and by deploying their resources in ways that allow them to create value. Some of these opportunities lie in the foreign markets, requiring strategies that leverage SMEs' skills and capabilities. 
Internationalization may be a complex and expensive process, which requires careful assessment of opportunities and the development and implementation of several strategies (George, Wiklund \& Zahra, 2005). For this reason, the internationalization cannot be explained by one theory. In studying entrepreneurship from a strategic perspective, researchers have used the resource-based view (RBV) to focus on entrepreneurial capabilities. RBV proposes that the firm's resources and capabilities are the source of its competitive advantage. In different firms the resources are various and often used underpowered (Barney, 1995). The resource-based view presents that the firm can get a competitive advantage only if it can take advantage of a particularly valuable resources, which none of its competitors will not be able to easily imitate. Only the use of such resources can lead to a permanent gain a competitive advantage (Hamel \& Prahalad, 1990).

A number of researchers have adopted a resource-based, or capabilities perspective, to empirically address the issue of the internationalization of SMEs. Among the first were Dhanaraj and Beamish (2003) who found the product development and market development capabilities of SMEs to successfully predict their internationalization performance. The market orientation is a valuable and rare resource which is difficult to imitate. It is considered as one of firm's internal capability, which may create a sustainable competitive advantage (Hultu, Ketchen \& Slater, 2005; Zhou et al., 2008). Knight and Cavusgil (2004) submit that market orientation provides the basis for firm's commitment to external markets. Market orientation can be internalized firm's internationalization process one of the antecedents of internationalization particularly when 1) market orientation develops and promotes learning process in foreign markets, and 2) firms which have high market orientation develop strong market capabilities, such as distribution networks, market knowledge and customer relationships, which provide for the firm special knowledge of foreign markets (Wright, Westhead \& Ucbasaran, 2007). Armario et al. (2008) indicate that a direct positive relationship exists between 
$\mathrm{MO}$ and a strategy of internationalization, and that the effect of $\mathrm{MO}$ on performance in foreign markets is moderated by knowledge acquisition and market commitment. Although researchers have focused on understanding the variety of factors affecting SMEs' internationalization, market orientation have not been the focus of these studies.

\section{Methodology}

The data for the research was collected as a part of a project "Growth for Wood Product Industry", which is implemented in co-operation of Seinäjoki University of Applied Sciences and Finnish Forest Centre. The project is funded by European Agricultural Fund for Rural Development.

\subsection{Measurement constructs}

Market orientation was measured using 20-item MARKOR-scale (Kohli, Jaworksi \& Kumar, 1993; Farrell \& Oczkowski, 1997). Cronbach's alpha for the measurement instrument was 0.77.

Marketing capabilities were measured among eight capabilities: market research, pricing, product/service development, distribution, marketing communications, marketing planning and management, customer relations and branding. Capabilities concerning market research, pricing, product/service development, distribution, marketing communications and marketing management were measured using items from Vorhies and Harker (2000). For customer relations and branding, items from Vorhies et al. (2011) were added for the instrument. The final instrument consisted of 24 items. Cronbach's alpha was 0.94. Seven point Likert scale was used.

Business performance was measured by Chapman and Kihn (2009). Their 10-item instrument is originally developed by Govindarajan and Fisher (1990). For this study, the original measurement instrument was adapted to Finnish SMEs and the final instrument uses 9 items and covers non- 
financial and financial factors. Items related to profit, equity ratio, liquidity, turnover, development of new products, market share, market development, personnel development and political-public affairs. Respondents were asked to rate their business performance relative to competitors during the past three years with five point Likert scale. Cronbach's alpha was 0.88 .

\subsection{Respondents and analysis methods}

The questionnaire was sent during spring 2016 to $504(=N)$ customer firms of Forest Centre. 425 firms located on Southern Ostrobothnia and 79 firms in Central Ostrobothnia. All firms were registered to work in the field of wood processing industry. The answering percent was low and therefore the firms were called and asked to answer the questionnaire either in the internet or by returning the questionnaire via mail. In the third round Forest Centre sent a request to answer the questionnaire via email to Central Ostrobothnian firms.

When the firms of retired entrepreneurs and firms who had gone in bankruptcy were removed from the original $\mathrm{N}$, the potential group of respondents downsized from 504 to 363 . After the reminders we received all together 101 answers, resulting to the answering percent of 28. 20 answers were given from Central Ostrobothnia (answering percent 32) and Southern Ostrobothnia 80 answers (answering percent 27). In addition, one respondent did not answer to the question of location. 31 $\%$ of the respondents were active in international markets, $69 \%$ had only domestic affairs.

Data was analyzed using SPSS 22 -software and Amos. Multicollinearity tests were used to show that there was no problem with collinearity. Linear regression analysis was made to test the relationships between variables. Regression analysis showed that market orientation did not have a direct effect on business performance, but marketing capability did. After that, path analysis was made using Amos. Path analysis is an extension of the regression model in which also indirect paths can be tested. 
The final model was tested separately for firms operating only in domestic markets and for firms operating in international markets. In the model, marketing capability fully mediates the effect of market orientation on business performance. Goodness of fit measures (NFI, CFI, RMSEA ja CMIN/DF) were used for model evaluation (Byrne, 2010).

\section{Results}

Figure 1 presents the empirical model and table 1 presents the model estimates with internationalized firms. Market orientation have an indirect effect on business performance mediated by marketing capability. The goodness of fit measures are good $(\mathrm{NFI}=0.98, \mathrm{CFI}=1.00$, RMSEA $=0.000, C M I N / D F=0.943, p=0.332)$. The model explains 36 percent of the variance of business performance. Market orientation has a direct and significant effect on marketing capability. Market orientation explains 74 percent of the variance of marketing capability. Marketing capability has a direct and significant effect on business performance (standardized regression weight 0.60). The indirect effect of market orientation is significant (standardized regression weight 0.52).

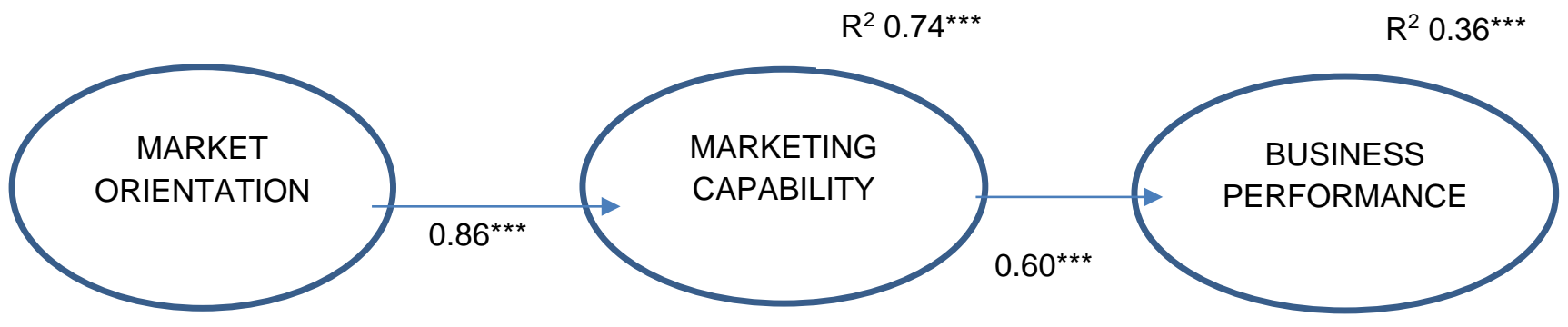

Figure 1. Empirical model for internationalized firms.

Table 1. Estimates and standardized regression weights of the model (internationalized firms)

\begin{tabular}{|l|rrrrr|}
\hline & & & & & Stand.regr. \\
& & Estimate & S.E. & C.R. & P \\
& & & & & weight \\
& & & & & \\
\hline Marketing capability $\leftarrow$ Market orientation & 1.099 & .125 & 8.770 & $* * *$ & .86 \\
\hline
\end{tabular}




\begin{tabular}{|c|c|c|c|c|c|}
\hline & Estimate & S.E. & C.R. & $P$ & $\begin{array}{l}\text { Stand.regr. } \\
\text { weight }\end{array}$ \\
\hline Business performance $\leftarrow$ Marketing capability & .413 & .103 & 4.002 & $* * *$ & .60 \\
\hline \multicolumn{6}{|l|}{$* \mathrm{p}<.05 . * * \mathrm{p}<.01 .{ }^{* * *} \mathrm{p}<.001$} \\
\hline
\end{tabular}

Figure 2 presents the empirical model and table 2 presents the model estimates with firms operating in domestic markets only. The estimates of the model differ from the model estimates for internationalized firms. Goodness of fit measures are not adequate for this model $(\mathrm{NFI}=.94 ; \mathrm{CFI}=$ $.95 ; \mathrm{RMSEA}=.201 ; \mathrm{CMIN} / \mathrm{DF}=3.776, \mathrm{p}=.052$ ). The model explains only 15 percent of the variance of business performance. The effect of marketing capability is smaller than in the model tested for internationalized firms. However, it still has a significant effect on business performance (standardized regression weight $0.39, \mathrm{p}=0.000$ ). Also the indirect effect of market orientation on business performance is smaller (standardized regression weight 0.29) than in the model tested for internationalized firms. However, market orientation has a direct and significant effect on marketing capability and it explains 54 percent of the variance of marketing capability.

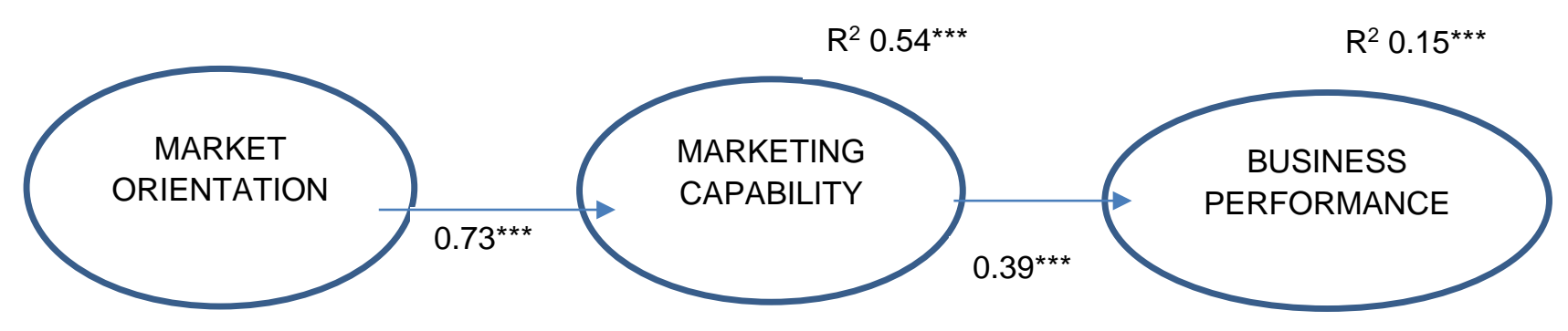

Figure 2. Empirical model for firms operating only in domestic markets.

Table 2. Estimates and standardized regression weights of the model (firms operating in domestic markets). 


\begin{tabular}{|l|rrrrrr|}
\hline & & & & & Stand.regr. \\
& Estimate & S.E. & C.R. & P & \\
& & & & & weight \\
\hline Marketing capability $\leftarrow$ Market orientation & .883 & .101 & 8.714 & $* * *$ & .73 \\
Business performance $\leftarrow$ Marketing capability & .297 & .088 & 3.369 & $* * *$ & .39 \\
\hline$* p<.05 .^{* *} p<.01 .^{* * *} p<.001$ & & & & & & \\
\hline
\end{tabular}

Marketing capability mediates the effect of market orientation on business performance with both groups: with internationalized firms and also with firms operating only in domestic markets. Marketing capability has a direct effect on business performance. However, model fit is not good in the model tested for firms operating in domestic markets and the standardized regression weights are smaller than in the model tested for internationalized firms. It seems that marketing capability and market orientation are even more important factors for firms operating in international markets. It could be assumed that firms operating in domestic markets have more knowledge about the market situation because the market is more stable.

\section{Conclusions and discussion}

The aim of this study was to analyze (1) the impact of market orientation and marketing capability on business performance with SMEs in the Forest sector and (2) the difference of this impact between internationalized SMEs and SMEs operating only in domestic markets in the Forest sector.

First, it can be said that both market orientation and marketing capability have an effect on business performance both with firms operating in domestic markets and firms operating in international markets. However, market orientation and marketing capability have even greater effects on business performance with firms operating in international markets. This indicates that SMEs aspiring 
international markets should pay attention on how knowledge of customers and competitors is acquired and used in the development of marketing operations. This, in turn, has a direct connection to the firm' success.

The study demonstrates that market orientation (i.e. how firms acquire and use knowledge of customers and competitors) effects directly to marketing capabilities and thus indirectly to the performance. A firm can consequently develop marketing capabilities by enhancing market orientation and with it be more successful. The study supports previous research; for example, Kirca et al. (2005) stated that market orientation and marketing capabilities affect the performance of the firm. The study confirms also that market orientation has indirect link to performance. GonzalesBenito et al. (2014) and Liao et al. (2011) noted that different factors may mediate the effects of market orientation.

Operating environment is relevant when assessing the effects of marketing capabilities on performance. In foreign markets operating firms need more marketing capabilities than firms operating only in domestic markets. This is in line with study of Wilde and Gudergan (2015) in which the effect of the competitive environment on the importance of marketing capabilities was indicated. A market oriented firm aims to achieve and get access to market intelligence when it comes to the competitors, customers, technology, government, and other environmental factors in a very systematic and proactive approach. Market orientation and marketing capabilities contribute to the superior firm performance (Morgan et al., 2009.) Morgan et al. (2009) also found that market orientation has a direct effect on firm's return on assets (ROI), and that marketing capabilities directly impact both ROA and perceived firm performance. As Knight and Cavusgil (2004) stated, market orientation is the basis for how the firm is linked to foreign markets and thus, it can be considered 
one of the prerequisites for the firm's internalization process. With it the firm learns from markets and develops capabilities to help firm succeed.

The study demonstrates that applying growth and internationalization of SMEs in Forest sector it should be primarily given attention to the development of firm's market orientation which, in turn, develops firm's marketing capabilities. Market orientation is as Wright et al. (2007) suggested, one of the factors that influence the internationalization of the firm but at the same time it can be seen as a determinant of marketing capabilities, which in turn, is very important for firm's performance in the international markets.

There are two major perspectives on the process of internationalization of SMEs. The first perceives the internationalization of SME as being a sequential process that leads from a domestic market to international markets in accordance with a "learning process", whereby knowledge of the new markets is acquired and resources are increasingly committed to those markets (Johnson \& Vahlne, 1990, 1997; Cavusgil, 1980). The second perspective, derived from the international entrepreneurship literature, contends that firm can be "born global" (Knight \& Cavusgil, 1996). The current state of research suggests that in mature industries in which environment change is minimal, the sequential perspective on internationalization is more appropriate, whereas, in growing industries, the second perspective provides a better understanding of the internationalization as phenomenon. In conclusion, the wood product industry is a business area closer to the former than the latter perspective. Due to the fact it can be concluded that the sequential internationalization process proceeds through the development of market orientation and learning processes by which capabilities such as marketing capabilities are developed. 
Research has also shown that the possession of certain competencies can facilitate the development of a company's internationalization strategy, especially in the earlier stages of the process (Li, Li \& Dalgic, 2004). The present study contributes to this line of research by investigating whether market orientation, understood as a specific corporate competence, constitutes as an antecedent to internationalization in SMEs in wood product industry.

From the behavioral perspective, market orientation has been defined as "the organization-wide generation of market intelligence pertaining to current and future customer needs, dissemination of the intelligence across departments, and organization-wide responsiveness to it" (Kohli \& Jaworski, 1990). As such, market orientation can also be understood as a resource. In the theory of resourcebased view market orientation is an intangible property of the firm that enables the firm to manage market information and deliver value to it's customers (Hunt and Lambe, 2000). But the acquisition of such knowledge in a single, specific context is not as relevant as the acquisition of the ability to analyze, understand, and respond to a range of contexts. Companies learn to learn (Armario et al., 2008). According to Day (1994), market-oriented companies develop "inside-out" capabilities, which connect the internal processes that define organizational capabilities with the external environment, thus allowing the company to be competitive by creating solid relationships with customers, distributors, and suppliers. These distinctive capabilities can be characterized as "market-sensing" and "customer-linking and channel-bonding." In this sense, these refer to marketing capabilities that in this study proved to be linked to the firm's business performance in the international markets.

Internationalization may imply costs arising from unfamiliarity with the local environment, from cultural, political and economic differences. International business scholars have highlighted that many of the challenges are typical of the difficulties associated with the liabilities of foreignness (e.g. lack of local information, unfamiliarity with local culture) and newness (e.g. establishing internal 
management systems, international relationships), if the new countries are dissimilar to the home country (Li, 2007). However, internationalization gives the opportunity to gain additional knowledge and experience, which in turn lead to competitive advantages in the form of quick adaptation to the consumer preferences and an ability to innovate and maintain high-quality products (Harrison et al., 2000). The major contribution of this study was to show how market orientation and marketing capabilities as distinctive competencies, support a firm's activities in foreign markets. In the Forest sector context, noteworthy findings were the positive influence of a firm's overall market orientation on its marketing capabilities and their positive relationship with firm's internationalization process. Capabilities in transformation and learning (as developed from market oriented behaviours) facilitate the process of turning information about foreign markets into an appropriate market response.

Every empirical research has certain limitations that restrict the generalizability of the findings. In this case, it is possible that if the study was conducted on other regions and countries in the world, the magnitude and direction of the relationship in the model may be different. The degree of economic development may account for distinct SME behaviour. This study was conducted with Forest sector, so the results could be different with other sectors. The low degree of internationalization of the firms in current data is also a restricting factor. Although the study has provided strong evidence in the support for the model, the relative small number of respondents represent another potential concern. However, the sample is fairly representative of the population and there was no evidence on nonresponse bias. Moreover, given the confirmatory nature of the study, the sample can be considered sufficient.

Future research could examine the interplay of market orientation and marketing capability in the internalization process of firms operating in other sectors. Based on in-depth interviews with British exporters, Diamantopoulos \& Cadogan (1996) revealed that there are different patterns of export 
market orientation, determined largely by organizational and environmental influences. It could be argued that the environment and the sector have some kind of effect on implementation of market oriented behaviors. The globalisation have changed the markets since Diamantopoulos' and Cadogan's research, so the patterns of market orientation in international context could be further researched. Furthermore, it would be interesting to find out, what role market orientation and marketing capability have in born global firms contradictory to firms where internationalization is a sequential, learning process. Recent studies of SMEs' internalization have highlighted the concept Global Mindset (e.g. Felicio, Caldeirinha \& Rodriques, 2012). The analytical capacity resulting from GM facilitates flexibility and adaptation to the local environment and at the same time sensitivity to the context (Huang \& Kung, 2011). GM could be the prerequisite for market orientation. This may be the next step of the study; are GM and MO interrelated.

\section{REFERENCES}

Acs, Z., Dana, LP., \& Jones, M. (2003), 'Toward new horizons: The internationalization of entrepreneurship', Journal of International Entrepreneurship, 1 (1), 5-12.

Armario, J., Ruiz, D. \& Armario E. (2008), 'Market orientation and internationalization in small and medium sized enterprises', Journal of Small Business Management, 46 (4), 485-511.

Bard, U. (2007), 'The role of market orientation and learning orientation in enhancing small firm business performance'. Vaasa: University of Vaasa. Acta Wasaensia 171.

Barney, J. (1995), 'Looking inside for competitive advantage', The Academy of Management Executive, 9 (4), 49-61.

Byrne, B. (2010), 'Structural Equation Modeling with AMOS. Basic Concepts, Applications, and Programming', 2nd edition. New York: Routledge. 
Cano, C., Carrillat, F. \& Jaramillo, F. (2004), 'A meta-analysis of the relationship between market orientation and business performance: evidence from five continents', International Journal of Research in Marketing, 21, 179-200.

Cavusgil, ST. (1980), 'On the internationalization process of firms'. European Research, 8 (6), 273-354.

Cavusgil, E., Seggie, S. \& Talay, M. B. (2007), 'Dynamic capabilities view: foundations and research agenda', Journal of Marketing Theory and Practice, 15 (2), 159-166.

Chapman, C. \& Khin, L-A. (2009), 'Information system integration, enabling control and performance'. Acounting, Organizations and Society, 34 (2), 151-169.

Chetty, S. \& Campbell-Hunt, C. (2003), 'Paths to internationalisation among small-to medium-sized firms: a global versus regional approach', European Journal of Marketing 37, 796-820.

Coeurderoy, R., Cowling, M., Licht, G. \& Murray, G. (2011), 'Young firm internationalization and survival: Empirical tests on a panel of 'adolescent' new technology-based firms in Germany and the UK', International Small Business Journal, March 8, OnlineFirst.

Coley, L., Mentzer, J. \& Cooper, M. (2010), 'Is "consumer orientation" a dimension of market orientation in consumer markets?', Journal of Marketing Theory and Practice, 18 (2), 141-154.

Coviello, N. \& McAuley, A. (1999), 'Internationalisation and the smaller firm: A review of contemporary empirical research'. Management International Review, 39 (3), 223-256.

Day, G. (1994), 'The capabilities of market-driven organizations', Journal of Marketing, 58 (4), 37-52.

Day, G. (2011), 'Closing the marketing capabilities gap'. Journal of Marketing, 75 (July 2011), 183195.

Dhanaraj, C. \& Beamish, PW. (2003), 'A resource-based approach to the study of export performance'. Journal of Small Business Management, 41 (3), 242-261.

Diamantopoulos, A. \& Cadogan, J. (1996), 'Internationalizing the market orientation construct: an indepth interview approach'. Journal of Strategic Marketing, 4 (1), 23-52. Published online: 28 Jul 2006. 
Ekeledo, I. \& Sivakumar, K. (2004), 'International market entry mode strategies of manufacturing firms and service firms: A resource-based perspective'. International Marketing Review, 21, 68101.

Farrell, M. \& Oczkowski, E. (1997), 'An analysis of the MKTOR and MARKOR measures of market orientation: An Austrian perspective'. Market Bulletin 1997 (8), 30-40.

Felicio, J.A., Caldeirinha, V.R \& Rodriques, R. (2012), 'Global mindset and the internationalization of small firms: The importance of the characteristics of entrepreneurs'. International Entrepreneurship and Management Journal, 8 (4), 467-485.

DOI: $10.1007 / \mathrm{s} 11365-012-0232-5$

Foley, A. \& Fahy, J. (2009), 'Seeing market orientation through a capabilities lens'. European Journal of Marketing, 43 (1/2), 13-20.

Freeman, S. \& Cavusgil, ST. (2007), 'Innovation, organizational capabilities, and the born-global firm', Journal of International Business Studies, 35 (3), 124-141.

George, G., Wiklund, J. \& Zahra, S. (2005), 'Ownership and internationalization of small firms'. Journal of Management, 31 (2), 210-233.

González-Benito, O. González-Benito, J. \& Muñoz-Gallego P. (2014), ‘On the Consequences of Market Orientation across Varied Environmental Dynamism and Competitive Intensity Levels'. Journal of Small Business Management, 52 (1), 1-21.

Govindaraja, V. \& Fisher, J. (1990), 'Strategy, control systems and resource sharing: effects on business-unit performance'. Academy of Management Journal, 33 (2), 259-285.

Hamel, G. \& Prahalad, KG. (1990), 'The core competence of the corporation'. Harvard Business review, 68 (3), 79-91.

Harris, L. (1999), 'Barriers to developing market orientation'. Journal of Applied Management Studies $8(1), 85-101$. 
Harrison, A.L., Dalkiran, E. \& Elsey, E. (2000), 'International Business: Global Competition from a European Perspective', Oxford University Press, Oxford.

Heino, P. (2011), 'Puurakentamisen osaaminen ja osaajat. Kansallinen kartoitus'. [national report] Metsäalan ennakointiyksikkö (Itä-Suomen yliopisto) ja Joensuun Tiedepuisto Oy. Available at: www.metsaennakointi.fi/tietoa/julkaisut.htm [Accessed 14. Apr. 2016].

Homburg, C., \& Pflesser, C. (2000), 'A Multiple-Layer Model of Marketing-Oriented Organizational Culture: Measurement Issues and Performance Outcomes'. Journal of Marketing Research, 37 (4), 449-462.

Hooley, G., Fahy, J., Cox, T., Bercas, J., Fonfara, K. \& Snoj, B. (1999), 'Marketing capabilities and firm performance: a hierarchial model'. Journal of Marketing Focused Management, 4 (3), 259-278. Huang, C-L \& Kung, F.H. (2011), 'Environmental consciousness and intellectual capital management: Evidence from Taiwan's manufacturing industry'. Management Decision, 49 (9), 1405-1425. Hult, G.T.M., Ketchen, D.J. \& Slater, S.F. (2005), 'Market orientation and performance: an integration of disparate approach'. Strategic Management Journal, 26 (12), 1173-1181.

Hunt, S., \& Lambe, J. (2000), 'Marketing's contribution to business strategy: Market orientation, relationship marketing and resourced-advantage theory', International Journal of Management Review, 2 (1), 17-43.

Hunt, S. \& Morgan, R. (1995), 'The comparative advantage theory of competition'. Journal of Marketing, 59 (October), 1-15.

Hurley, R. \& Hult, T. (1998), 'Innovation, market orientation and organizational learning: an integration and empirical examination'. Journal of Marketing, 62 (July), 42-54.

Hurmekoski, E., Jonsson, R. \& Nord, T. (2015), 'Context, drivers and future potential for frame multistory construction in Europe'. Technological Forecasting \& Social Change, 99, 181-196.

Ireland, R., Hitt, M. \& Simon, D. (2003), 'A model of strategic entrepreneurship: The construct and its dimensions'. Journal of Management, 29 (6), 963-989. 
Jain, R., Jain, C. \& Jain, P. (2013), 'Integrated Framework of Antecedents and Effects of Market Orientation. A Qualitative Review', Management and Labour Studies, 38 (4), 425-445.

Jaworski, B. \& Kohli, A. (1993), 'Market orientation: antecedents and consequences', Journal of Marketing, 57 (3), 53-70.

Joensuu, S., Viljamaa, A., Katajavirta, M., Kettunen, S. \& Mäkelä, A-M. (2015), 'Markkinaorientaatio ja markkinointikyvykkyys eteläpohjalaisissa kasvuyrityksissä', Seinäjoen ammattikorkeakoulu. Available at: https://theseus.fi/handle/10024/97182.

Johnson, J. \& Vahlne E. (1990), 'The mechanism of internationalization', International Marketing Review, 7 (4), 11-24.

Johnson, J. \& Vahlne, J-E. (2009), 'The Uppsala internationalization process model revised: From liability of foreigness to liability of outsidership', Journal of International Business Studies, 49, 1411-1431.

Kettunen, L. (2013), 'MSO:n selvitys "Puutuotealan kasvun ja kansainvälistymisen esteet ja ratkaisut"', Työ- ja elinkeinoministeriö: Metsäalan strateginen ohjelma, Ministry of Economic Affairs and Employment 26/2013.

Kirca, A., Jayachandran, S. Bearden, W. (2005), 'Market orientation: a meta-analytic review and assessment of its antecedents and impact on performance', Journal of marketing, 69 (2), 24-41. Knight, G. (2000), 'Entrepreneurship and marketing strategy: The SME under globalization', Journal of International Marketing, 8 (2), 12-32.

Knight, G. \& ST. Cavusgil (1996), 'The Born Global firm: A challenge to traditional internationalization theory', in S. T. Cavusgil and T. K. Madsen (eds.), Export internationalizing research-enrichment and challenges, Advances in International Marketing, 8. New York: JAI Press, 11- 26.

Knight, GA. \& Cavusgil, S. (2004), 'Innovation, organizational capabilities and the born-global firm', Journal of International Business Studies, 35 (3), 124-141. 
Kohli, A., Jaworski, B. \& Kumar, A. (1993), 'MARKOR: a measure of market orientation', Journal of Marketing Research, 30 (4), 467-477.

Liao, S.-H., Chang, W., Wu, C. \& Katrichis, J. (2011), 'A survey of market orientation research (19952008)'. Industrial Marketing Management, 40 (2), 301-310.

Li, L. (2007), 'Multinationality and performance: a synthetic review and research agenda', International journal of management review, 9 (2), 117-139.

Li, L., Li, D. \& Dalgic, T. (2004), 'Internationalization process of small and medium-sized enterprises: Toward a hybrid Mmdel of experiential learning and planning', Management International Review, 44 (1), 93-117.

Loukasmäki, P. (2015), 'Wood industry'. Ministry of Employment and the Economy 4/2015.

Matsuno, K., Mentzer, J. \& Özsomer, A. (2002), 'The effects of entrepreneurial proclivity and market orientation on business performance', Journal of Marketing, 66 (3), 18-32.

Maydeu-Olivares, A. \& Lado, N. (2003), 'Market orientation and business economic performance. A mediated model', International Journal of Service Industry Management, 14 (3), 284-309.

Merrilees, B., Rundle-Thiele, S. \& Lye, A. (2011), 'Marketing capabilities: antecedents and implications for B2B SME performance', Industrial Marketing Management, 40, 368-375.

Mtigwe, B. (2005), 'The entrepreneurial firm internationalization process in the Southern African context: A comparative approach', International Journal of Entrepreneurial Behaviour \& Research, 11, 358-377.

Moen, O. \& Servais, P. (2002), 'Born global or gradual global? Examining the export behavior of small and medium-sized enterprises', Journal of International Marketing, 10 (3), 49-72.

Morgan, T., Anokhin, S., Kretinin, A., Frishammar, J. (2015), 'The dard side of the entrepreneurial orientation and market orientation interplay: A new product development perspective', International Small Business Journal, 33 (7), 731-751. 
Morgan N., Vorhies, D. \& Mason C. (2009), 'Market orientation, market capabilities, and firm performance', Strategic Management Journal, 30 (8), 909-920.

Narver, J. \& Slater, S. (1990), 'The effect of a market orientation on business profitability', Journal of Marketing, 54 (October), 20-35.

Pelham, A. (1997), 'Mediating Influences on the relationship between market orientation and profitability in small industrial firms', Journal of Marketing Theory and Practice, 5, 55-77.

Pelham, A. (2000), 'Market orientation and other potential influences on performance in small and medium-sized manufacturing firms'. Journal of Small Business Management, 38 (1), 48-67.

Reijonen, H. \& Komppula, R. (2010), 'The adoption of market orientation in SMEs: required capabilities and relation to success, Journal of Strategic Marketing, 18 (1), 19-37.

Ruzzier, M., Hisrich, RD. \& Antonic, B. (2006), 'SME internationalization research: Past, present and future', Journal of Small Business and Enterprise Development, 13 (4), 476-497.

Shin, S. \& Aiken, K. (2012), 'The mediating role of marketing capability: evidence from Korean companies', Asia Pacific Journal of Marketing and Logistics, 24 (4), 658-677.

Slater, S. \& Narver, J. (1994), 'Does competitive environment moderate the market orientationperformance relationship?', Journal of Marketing 58, 46-55.

Slater, S. \& Narver, J. (1998), 'Customer-led and market-oriented: let's not confuse the two', Strategic Marketing Journal, 19, 1001-1006.

Sousa, CMP., Martinez-Lopez, FJ. \& Coelho, F. (2008), 'The determinants of export performance: A review of the research in the literature between 1998 and 2005', International Journal of Management Reviews, 10 (4), 343-374.

Spillan, J., Kara, A., King D. \& McGinnis, M. (2013), 'Market orientation and firm performance: An empirical analysis of Ghanaian microenterprises', Journal of Global Marketing, 26 (5), 257-272.

Srivastava, R., Fahey, L. \& Christensen, H.K. (2001), 'The resource-based view and marketing: the role of market-based assets in gaining competitive advantage', Journal of Management 27, 777-802. 
Valtioneuvoston viestintäosasto (2016), 'Hallitus päivitti yrittäjyyttä ja työllisyyttä koskevia kärkihankkeitaan', [web page]. Bulletin 155. Available at: http://valtioneuvosto.fi/artikkeli/Lasset publisher/hallitus-paivitti-yrittajyytta-ja-tyollisyytta-koskevia-

\section{karkihankkeitaan? 101 INSTANCE 3wys|Lo1Z0ni groupld=10616 [Accessed 8. Aug. 2016]}

Verhoef, P., Leeflang, P., Reiner, J., Natter, M., Barker, W., Grinstein, A., Gustafsson, A., Morrison, P. \& Saunders, J. (2011), 'Cross-national investigation into the marketing department's influence within the firm: toward initial empirical generalizations', Journal of International Marketing, 19 (3), 59-86.

Vorhies, D. \& Harker, M. 2000, 'The capabilities and performance advantages of market-driven firms: an empirical investigation', Australian Journal of Management, 25 (2), 145-171.

Vorhies, D., Orr, L. \& Bush, V. (2011), 'Improving customer-focused marketing capabilities and firm financial performance via marketing exploration and exploitation', Journal of the Academy of Marketing Science, 39 (5), 736-756.

Wilden, R. \& Gudergan, S. (2015), 'The impact of dynamic capabilities on operational marketing and technological capabilities: investigating the role of environmental turbulence', Journal of the Academy of Marketing Science, 43, 181-199.

Wright, M., Westhead, P. \& Ucbasaran, D. (2007), 'Internationalization of small and medium-sized enterprises (SMEs) and international entrepreneurship: a critique and policy implications', Regional Studies, 41 (7), 1013-1030.

Zhou, K.Z., Li, JJ., Zhou, N. \& Su, C. (2008), 'Market orientation, job satisfaction, product quality and firm performance: evidence from China', Strategic Management Journal, 29 (9), 985-1000. 